\title{
Avoiding genetic genocide: understanding good intentions and eugenics in the complex dialogue between the medical and disability communities
}

Paul Steven Miller, JD ${ }^{1,2}$ and Rebecca Leah Levine, MPH, JD ${ }^{1}$

${ }^{1}$ University of Washington School of Law, Seattle, Washington, USA

\begin{abstract}
The relationship between the medical and disability communities is complex and is influenced by historical, social, and cultural factors. Although clinicians, health-care researchers, and people with disabilities all work from the standpoint of the best interest of disabled individuals, the notion of what actually is "best" is often understood quite differently among these constituencies. Eugenics campaigns, legal restrictions on reproductive and other freedoms, and prenatal testing recommendations predicated on the lesser worth of persons with disabilities have all contributed toward the historic trauma experienced by the disability community, particularly with respect to medical genetics. One premise of personalized medicine is that different individuals require different solutions. Disabled persons' experiences are a reminder that these solutions can be best realized by maintaining awareness and sensitivity in a complex ethical and moral terrain. Geneticists should recognize that their research may have implications for those with disabilities; they should recognize the impact of the historical trauma of the eugenics movement, and seek to involve people with disabilities in discussions about policies that affect them. Dialogue can be messy and uncomfortable, but it is the only way to avoid the mistakes of the past and to ensure a more equitable, and healthful, future.
\end{abstract}

\section{Keywords}

disability; eugenics; healthcare; provider-patient relationship; stigma

"But a lot of people who interact with me treat me as if I don't know what I'm doing, as if they in fact know what's best for me, and that if I don't go along with what they're expecting of me, then I'm either stubbornly refusing to do what is good for me or unaware of what is good for me. The idea that I already have a better idea of what's good and bad for me than most people, doesn't cross their mind, nor does the idea that I'm more able to do things overall if they're done the way I think best, not some other way."

—Disability blogger "ballastexistenz"1

\section{INTRODUCTION}

It has been more than 50 years since Watson and Crick's groundbreaking discovery of the double helix structure of DNA. The profound developments that have taken place during our

\footnotetext{
Correspondence: Rebecca Leah Levine (Levine.rebecca@gmail.com).

${ }^{2}$ Deceased

DISCLOSURE

The authors declare no conflict of interest.
} 
lifetimes in the science of genetics are staggering. More staggering still are the boundless horizons and the promised and unimagined applications of the work of the many scientists involved in today's genetics revolution. There can be no doubt that a firm and unwavering commitment to the betterment of humankind has fueled this tireless effort. The genetics revolution is in full swing and, with apologies to Aldous Huxley, we stand at the precipice of a brave new world. Nonetheless, the question remains: how will science, history, and culture intersect in this new era?

In Brave New World, Huxley's anti-utopian novel of a future built upon genetic engineering, Mustapha Mond, the Resident World Controller for Western Europe, states, "Every discovery in pure science is potentially subversive; even science must sometimes be treated as a possible enemy. Yes, even science."2 History has taught us that the wonders of science hold unique power to sway and seduce, and sometimes even corrupt, the course of human nature. Scientific advances never exist in a vacuum; they are always viewed through a social, ethical, legal, and political prism. Disabled individuals can offer a unique perspective that will help scientists, clinicians, and consumers of genetic health services chart a way through this new ethical territory. Moreover, without the support and understanding of people with disabilities, genetic research will face a loss of confidence from the very community that it presumes to benefit.

Although genetics can provide positive medical treatments for certain impairments, two concerns lead to anxiety over a possible return to the eugenics era. First, the disability community lacks a voice in the genetics policy arena. Second, the promise of genetic research is often described as the elimination of disabilities that occur naturally within the population. This leads disabled people to view the genetics revolution as one designed to prevent the birth of people like them. Scientists caught up in the excitement of genetics discoveries can forget that life with a disability can be rich and fulfilling. "Health" is a subjective characterization, most often defined by health professionals, researchers, and the insurance industry, and not by people with disabilities.

Although modern genetics is a far cry from the pseudoscientific days of eugenics, the history of the eugenics movement shapes and informs how people with disabilities view genetics, science, and the genome revolution. The eugenics movement found fertile soil within the American scientific, medical, and university elite. ${ }^{3}$ In the US Supreme Court, in Buck v. Bell, eugenics was inscribed as a hallmark of American jurisprudence by Oliver Wendell Holmes, one of the most influential judges in American law. ${ }^{4}$ To some, the Supreme Court's decision to uphold forced sterilization is a historic artifact of past injustices. For many in the disability community, it is viewed as a prophetic vision of a future that threatens their existence. Communities oppressed by the scientific misuse of the eugenics movement are apt to be wary when similar genetic tools are repackaged.

The concern over genetic genocide is not misplaced paranoia on the part of the disability community. James Watson, the Nobel Prize-winning discoverer of the "double helix," has written that "seeing the bright side of being handicapped is like praising the virtues of extreme poverty." Like Charles Davenport, a leader in the early eugenics movement in the United States, Watson strongly supports the controlling of genetic destinies: "Working intelligently and wisely to see that good genes—not bad ones—dominate as many lives as possible is the truly moral way for us to proceed." 6 Watson urges the scientific community to strive for human perfection because, after all, "you always want the perfect girl."7

Other contemporary leaders in bioethics and science have expressed similar views. Peter Singer argues that "killing a defective infant is not morally equivalent to killing a person. Very often it is not wrong at all." 8 Even Margaret Sanger, the founder of Planned 
Parenthood, wrote in her 1922 book, The Pivot of Civilization: "The most urgent problem today is how to limit and discourage the over-fertility of the mentally and physically defective." 9

There is no question that the genetic revolution holds great promise, and that today's doctors and researchers have good intentions in seeking to improve human health for all. However, technological advances do not automatically translate into producing clinicians who understand, listen to, and value the needs and goals of their disabled patients. For the genetic revolution to truly flourish, the disability community and the medical/scientific community need to better understand each other's perspective and past, and acknowledge the implications of genetics research for the present and the future.

\section{HISTORICAL TRAUMA AND THE DISABILITY COMMUNITY}

The term "historical trauma" is generally defined as a collective emotional and psychological injury to a group of people, over the life span of the individual and across generations, resulting from a cataclysmic history of genocide ${ }^{10}$ Historical trauma is most frequently associated with the postcolonial contact of the Native American population with settlers and the US government, including well-known incidents of wars, genocide, relocation to reservations, and forced termination of language and religion. ${ }^{11}$ However, numerous other groups have suffered historically traumatic events that continue to resonate within those populations even today: the slavery of African Americans, the Jewish Holocaust, the internment of Japanese Americans during World War II and, more recently, the impact on Muslims of events surrounding the conflicts in Iraq and Afghanistan.

The disability community has experienced historical trauma as well, but in a very different sense. Rather than coming out of violent racism, ethnic cleansing, or armed conflict, it derives from inherent biases and misrepresentations, in part from within the medical and scientific communities, about life with a disability. ${ }^{12,13}$ Rather than guns or gas chambers, the weapon of destruction is misguided scientific policy for the sake of "betterment of the whole." Events leading to historical trauma in the disability community include the development of the eugenics movement by Charles Davenport and Francis Galton in the United States and the UK, respectively; institutionalization of persons with mental and physical disabilities; forced sterilization ${ }^{14}$; and early twentieth century US immigration laws whose object was to exclude "the morally, mentally, and physically deficient."15

In Buck v. Bell, the US Supreme Court upheld Virginia's compulsory sterilization laws as applied to prevent the reproduction of "mentally defective" people. ${ }^{4}$ Justice Oliver Wendell Holmes infamously wrote for the Court:

It is better for all the world, if instead of waiting to execute degenerate offspring for crime, or to let them starve for their imbecility, society can prevent those who are manifestly unfit from continuing their kind. The principle that sustains compulsory vaccination is broad enough to cover cutting the fallopian tubes. Three generations of imbeciles are enough. ${ }^{4}$

With 29 other states maintaining similar sterilization laws, an estimated 65,000 Americans were forcibly sterilized over the course of the twentieth century based on this brand of pseudo-science. 16

Buck v. Bell reflects the dark and dangerous nature of genetic "progress." The idea that entire classes of people could be eliminated by removing their ability to reproduce was accepted widely at the beginning of the twentieth century as a way to secure a more perfect society. ${ }^{3}$ Today, Buck v. Bell is regarded as one of the Supreme Court's most egregious and flawed opinions, alongside Dred Scott v. Sandford, ${ }^{17}$ Plessy v. Ferguson, ${ }^{18}$ and others, and 
represents eugenic principles that have now been repudiated. ${ }^{3}$ Although Buck v. Bell has never been formally overruled, Holmes' reasoning was thought to be rejected in Skinner $v$. Oklahoma, when the Supreme Court struck down an Oklahoma law on equal protection grounds. ${ }^{19}$ In addition, some scholars argue that the fundamental right to privacy, protected by Roe v. Wade, 410 U.S. 113 (1973) (and other earlier cases such as Griswold v. Connecticut and Eisenstadt v. Baird), will also prevent involuntary sterilization. ${ }^{20,21}$

Despite the present-day abhorrence of Holmes' opinion in Buck v. Bell, 27 states continued to have sterilization laws subjecting "feeble-minded" or "mentally deficient" individuals to sterilization as late as $1968 .^{22}$ The validity of these statutes has generally been upheld by the police authorities of the respective states, as long as due process rights are protected. ${ }^{23}$ For example, in 1976, the Court in North Carolina Ass'n for Retarded Children v. State of N.C. rationalized its ruling upholding sterilization by explaining:

The legislative dual purpose to prevent the birth of a defective child or the birth of a nondefective child that cannot be cared for by its parent reflects a compelling state interest and the classification rests upon a difference having a fair and substantial relation to the object of the legislation and does not, therefore, violate the Equal Protection Clause of the Fourteenth Amendment of the Constitution of the United States. ${ }^{24}$

In addition to sterilization laws, many laws limit the ability of disabled individuals to marry and parent their own children, despite the recognition by the US Supreme Court that such rights are fundamental. ${ }^{25-27}$ For example, in 1953, a Pennsylvania statute prohibited granting a marriage certificate to any person who had epilepsy or was "weak-minded, insane, or ... of unsound mind," except under court order. ${ }^{27}$ As of 2007, more than 30 states still had statutes that banned or restricted the right of persons with disabilities to marry. ${ }^{28}$

Parenting rights of disabled people are also limited, the purported justification being the protection of the health and safety of children who perhaps would not be adequately cared for by a disabled caretaker. ${ }^{27}$ In In re Marriage of Carney, 24 Cal.3d 725 (1979) the California Supreme Court overruled the decision of a trial judge to remove a quadriplegic person's children from his custody solely for the reason that he had a physical handicap. In that decision, the Court made reference to a previous California case, Adoption of Richardson, 251 Cal.App.2d 222 (1967), wherein the trial court denied a couple's petition to adopt a baby boy because both the prospective parents were deaf-mutes. In 1988, authorities in California took away two children from Tiffany Callo who had cerebral palsy, and placed them in foster care soon after they were born. ${ }^{29,30}$ More recently, in 2007, the Montana Department of Labor and Industry found that state child protective service employees had unlawfully discriminated against a tetraplegic woman while assessing her ability to care for her son; and that, when the woman, who had limited use of her arms and hands, lodged a complaint, the employees retaliated against her. ${ }^{31}$ As these examples demonstrate, even the most fundamental of rights have not been protected with equal vigor for those with disabilities.

The trauma faced by the disability community is not rooted in hatred. While the English language has the words racism, sexism, and homophobia, reflecting prejudices based on color, gender, and sexual preference, respectively, there is in fact no generally accepted word that reflects animus toward persons with disabilities. The only word that the disability community may view as describing animus toward them is eugenics; this is ironic, as the word was developed to describe a process intended to benefit society. ${ }^{32}$

A sense of historical trauma generated by the medical profession resonates within the disability community today. The efforts on the part of medical science to reduce or eliminate 
disability from the population are viewed by many in the disability community as characteristic of the relationship between the medical and disability communities. Although medical interventions in persons with disabilities are often made with good intentions, their use often fails to take into account or comply with what the disabled patient views as his or her own personal interests or needs, or what is in the best interest of the disability community. A blogger makes this request to physical therapists and "body workers": "You may be excited about what you can do for me, but my goals, as recorded on your intake sheet, are more important ... I rely on your expertise in your discipline, but I also need you to know that I am the expert on my particular body." ${ }^{33}$ Another blogger, who has been paralyzed since the age of 18 , asks for changes in societal attitudes rather than physical changes to his body: "I need not be saved by science or technology but rather expect, demand really, that society accept me for the man I am. After all, I am as human as is any person with or without a disability." ${ }^{34}$

In 2004, the case of "Ashley X" laid bare this clash between the medical professionals and the disability community, although it was not a case involving genetic disability per se. The parents of Ashley, a 6-y-old girl with profound developmental disabilities, sought treatment to keep their daughter "small" and to prevent her from growing and developing sexually. ${ }^{35}$ The parents requested that their daughter be administered high doses of hormones and asked that her breast buds and uterus be removed so that she would remain smaller and lighter. This so-called "Ashley Treatment" was performed by doctors at Children's Hospital in Seattle, WA, after being sanctioned by the hospital ethics committee. ${ }^{36}$

Washington State law holds that the parents of a child with a developmental disability do not have the authority to consent to the involuntary sterilization of their child because the procedure infringes on the child's fundamental liberty and privacy interests. ${ }^{37}$ The law further stipulates that surgeries such as those performed on Ashley can be done only under court order, and after the court has had the opportunity to consider the opinion of a guardian appointed to represent the rights and interests of the patient. Yet the hospital authorized the procedure in the absence of an appointed guardian or court order. Ashley's constitutional rights were disregarded in favor of what her parents and doctors thought was best from their own perspectives, without regard to what may have been best from Ashley's perspective. The disability community immediately recognized the impact of Ashley's case. ${ }^{36}$

In his blog, Planet of the Blind, Steve Kuusisto, a professor of creative writing who is blind, emphasized that Ashley's parents prioritized their own desire for accommodation:

When we imagine that by means of surgery and drugs that we're doing a good thing by making another person's body and life fit our own convenience we are essentially confusing utility with ethics. Ashley, who cannot speak for herself has been rendered an object in this process. Those in the medical ethics and disability communities who see a connection between this procedure and eugenics are in my view not wrong. ${ }^{38}$

The medical decision to perform the Ashley Treatment is a very personal issue for writer and disability rights activist Anne McDonald. Like Ashley, McDonald was born with a static encephalopathy. After years of medical neglect at a state institution, she began receiving proper schooling and nutrition, eventually attaining an average height and weight and graduating from university in Australia, her home country. "Though I still can't walk, talk or feed myself, I'm an enthusiastic traveler. My size has never got in the way, though my hip flask of Bundy rum often causes alarm at airport security." ${ }^{39}$ Referring to her own story as the "reverse of Ashley's," she writes: "Only someone like me who has lain in a cot year after year hoping that someone would give her a chance can know the horror of being treated as if you were totally without conscious thought." 39 
The medical community's willingness to accept and ratify the Ashley Treatment, and the sense of moral outrage it inspired in the disability community, illustrate the ongoing nature of historical trauma within the disability community. When seeking medical care, disabled individuals often find that health-care professionals lack sufficient knowledge about how to care for patients with intellectual or developmental disabilities, fail to communicate directly with patients, and display an insensitivity to these patients' needs. ${ }^{40}$ The medical community must recognize the historical trauma suffered by the disability community in order to understand why many disabled individuals are wary of anything labeled as a quick fix to "eliminate" a disability.

\section{GENETICS AS THE "CURE”}

When the medical and scientific communities praise genetics as a revolutionary new tool to cure or eliminate disability, the disability community hears an aggressive lyric that is paternalistic and perhaps genocidal. A sincere desire to cure through genetic advances comes across as something more nefarious when considered in the context of disability history. Genetics, as currently defined, practiced, and presented to the public, reinforces the stigma of disabled individuals as defective individuals. ${ }^{41}$

Although the disability community and the scientific, research, and medical communities all value what is in the "best" interest of disabled individuals, the notion of what is actually "best" is quite different among these groups. The view-point of a disabled person may be completely different from that of a healthcare provider as regards the appropriate kind of healthcare. Similarly, the goals of the scientific and research communities may diverge from the concerns and desires of the disability community.

\section{Medical paternalism and people with disabilities}

Traditionally, patients were expected to trust their physicians and make their health-care decisions on the basis of a clinician's professional opinion. The provider-patient relationship was thought to mirror the relationship between a parent and child. ${ }^{42}$ In this scenario, the clinician, by virtue of his training and expertise, had complete authority over the patient and it was his or her duty to act in the best interests of that patient; the patient's preferences and opinions were not valued. The American Medical Association's Code of Ethics in 1847 reads:

The obedience of a patient to the prescriptions of his physician should be prompt and implicit. He should never permit his own crude opinions as to their fitness, to influence his attention to them. A failure in one particular may render an otherwise judicious treatment dangerous, even fatal. ${ }^{43}$

This paternalistic model has proven unsatisfactory to many patients who seek a more egalitarian approach to medicine and treatment. ${ }^{44}$ Over the past few decades there has been a dramatic change in the provider-patient relationship, reflecting the patients' desire for autonomy and equality in decision making. Some examples include the American Medical Association's updated recognition of patient autonomy, ${ }^{45}$ the concept of "enhanced autonomy" that encourages full and frank discussion and negotiation between clinicians and patients, ${ }^{46}$ and a patient-centered model of care that recognizes equality between the clinician and patient and their relative areas of expertise. ${ }^{47}$ Despite this shift, the relationship between mentally and physically disabled individuals and their providers continues to be defined by the traditional, paternalistic approach. In his book, Nothing About Us Without Us, James Charlton describes the general paternalistic sensibility expressed toward disabled individuals: 
Paternalism ... is the experience of the waiter asking a companion of a person with a disability, "What does she want to eat?" It is the institutionalization of people against their wishes. It is the child taught only handicrafts, or the charity pleading for money to help the crippled kids ... It is most of all, however, the assumption that people with disabilities are intrinsically inferior and unable to take responsibility for their own lives. ${ }^{48}$

This paternalistic approach applies to both physical and mental health disabilities. The National Council on Disability explains:

After years of contact with a system that routinely does not recognize their preferences or desires, many people with psychiatric disabilities become resigned to their fate and cease to protest openly. Although this is described in the psychiatric literature as "compliance," it is actually learned helplessness that is incompatible with hope and with the possibility of recovery. ${ }^{49}$

Despite the lack of a formal body of literature on the subject, many individuals with disabilities have chosen to express their frustration with their health-care providers through blogging, revealing their difficulties through personal accounts of disturbing experiences. Blogging allows disabled individuals to express these encounters "out loud" and share them with others in the disability community who face similar challenges. These online threads offer important insight into the complex relationship between the medical and disability communities, and ways in which this relationship can be improved. For instance, addressing providers, a blogger writes:

[W]e may not communicate pain in traditional ways. So believe us if we say we hurt, even if it doesn't look like we hurt ... Nobody should be hung up on, just because they sound like a child or are hard to understand ... And some people are going to need a bit of a different procedure than you're [sic] staff is used to. Give them the authority to deviate in these cases. It's hard enough for us to even get to the point where we are willing to try to see a doctor. ${ }^{50}$

People with disabilities can in fact be underserved by clinicians who fail to listen in the same way they would listen to a patient who is not perceived to be disabled. Clinicians may also fail to present or even consider alternative treatments and options when dealing with a disabled patient out of fear that the patient will make the "wrong" choice. In this way, care is provided in a categorically different manner based largely on clinicians' inherent biases and value judgments about life with a disability.

Medical personnel often assume that the quality of life of a disabled individual is inversely proportional to the degree of physical or mental impairment. ${ }^{51}$ Negative assumptions about disabilities may influence the counseling clinicians provide ${ }^{52}$ and impair clinicians' ability to perceive the positive quality of life experienced by people with disabilities ${ }^{53}$ Lack of experience with disability is an important factor in these attitudes. Interaction with disabled individuals and exposure to courses addressing disability are associated with more favorable attitudes toward people with a disability. ${ }^{51}$ Familiarizing future health professionals with disability training and sensitivity may enable them to move away from paternalism and recognize that a disabled person is an individual with knowledge and experience about how to best navigate his or her own life. ${ }^{54}$

\section{The impact of genetic technology on the medical model of disability}

Although genetic technology may provide relief for some physiological impairments, the view of genetics as an all-encompassing medical solution forces disabled people "to fight continually to be recognized as the legitimate subjects of our own lives." 55 The single-track medical focus on cure and a so-called "technological imperative in modern medicine" 56 is 
frustrating to those who live with genetic disabilities. For example, one blogger remarks that medical professionals are notorious for rating "our lives as much worse than we rate them. They imagine our lives to be an endless struggle against a sea of 'can't', to be pitied maybe, to be fixed definitely where possible, but not to be considered okay as we are." 57 Another blogger with a genetic skin condition writes: "My problems with the medical treatment I receive stem from the fact that doctors are not trained in how to deal with and serve patients who have chronic disabilities that they cannot cure." 58 Genetics, if viewed as the way to rid the world of disability and cure disabled people, is a frightening proposition for those who live with a disability and who have accepted who they are. "Difference," says one mother of a 10-year-old with dwarfism, "is what makes the world go round." 59

Two main frameworks for representing the concept of disability have emerged in the literature: the medical model and the social (or civil rights) model. The medical model remains the predominant view of disability in our culture, and conceptualizes disability as an illness or disease that requires intervention. Under the medical model framework, disability is a medical term used to denote an incapacity "whose consequence was functional limitations assumed to result from physical or mental impairment." 60 From this standpoint, many health professionals and researchers understand disability as something that must be cured or prevented through therapy, treatment, or selective termination of pregnancy. ${ }^{12}$ In contrast, the social model of disability views disability as a social construct whereby society defines those with physiological impairments as "not normal." 12 According to this model, "the experience of disability is not inherent or inevitable given a particular medical condition; it depends upon the particular social context in which one lives and functions," including institutional, structural, and attitudinal barriers established by society. ${ }^{61,62}$ Whereas the medical model focuses on providing medical solutions to fit the individual into mainstream society, the social model is intent on changing society to embrace the individual. Disability is, of course, much more multifaceted and complex than the representations provided by these generalized frameworks. ${ }^{63}$ Nevertheless, they are useful in understanding the relationship between people with disabilities and health professionals.

The influence of the medical model is exemplified in prenatal screening for Down syndrome, followed by the offer of pregnancy termination when a fetus is found to be affected. Practice bulletins of the American College of Obstetricians and Gynecologists have recommended universal prenatal screening for Down syndrome since 1985, with regular updates as prenatal testing technology has evolved. ${ }^{64,65}$ Termination rates as high as 80 $90 \%$ have been reported in some centers following confirmation of Down syndrome in the fetus (e.g., ref. ${ }^{66}$ ). This screening has resulted in a reduction in Down syndrome live births in many locations (e.g., refs. ${ }^{67-70}$ ), although the trend toward older maternal age has blunted this effect in some regions (e.g., ref. ${ }^{71}$ ). A new noninvasive technology utilizing fetal cells from maternal serum allows for screening early in pregnancy, ${ }^{72}$ potentially increasing termination rates. Those who encourage termination assume that life with a disability is less valued and desired than the life of an able-bodied individual, ${ }^{73}$ yet individuals with Down syndrome can and do live fulfilling lives. ${ }^{74}$ Rarely does the nondisabled community hear about disabled individuals who live ordinary lives and experience pain and pleasure like everyone else. ${ }^{53,74,75}$

In another example, doctors may propose cochlear implant surgery for a deaf child out of compassion and a genuine desire to improve the quality of life for that child. ${ }^{76}$ Clinicians may not fully understand the possibility that this intervention can offend deaf individuals, labeling them as defective and attempting to fix something that is not broken. The medical model's values regarding a disabled person's quality of life simply do not reflect the values of the disabled individual or of the disability community as a whole. ${ }^{77}$ 
The emergence of individualized genomic medicine may allow for medical care focused on the optimal preventative, diagnostic, and therapeutic approach for each person. This individualized approach may prove to be successful for many people living with disabilities, by narrowing the focus to the individual. However, as long as misinformed stereotypes of the lives and needs of disabled persons continue, individualized medicine will posit a "correct" medical course of action for people living with certain conditions. Advances in technology do not ensure that clinicians will listen with an open mind to the needs and goals of their disabled patients. Unless underlying assumptions are recognized and modernized, individualized care has the potential to highlight and reinforce the "cure" instinct in clinicians rather than the more appropriate goal of responding to the desire of disabled patients to maintain their overall physical and mental health.

\section{MOVING FORWARD: AVOIDING GENETIC GENOCIDE}

There are very few disabled people who reject all medical intervention; many do seek treatment to ameliorate their impairment when possible, or to maintain the status quo. ${ }^{78,79}$ However, it should never be assumed that all disabled individuals wish they were "normal." Backing away from an all-or-nothing approach to the use of genetic technology, Tom Shakespeare argues that it is time to recognize that impairments occur along a continuum. ${ }^{12}$ On one end of the spectrum are impairments like deafness and dwarfism-conditions that have social consequences but do not involve physical pain or suffering. On the other end of the spectrum are conditions such as Tay-Sachs that cause major suffering and lead to markedly premature death. Similarly, a distinction can be made between conditions that progress steadily toward death and static impairments that do not have a significant impact on health or life expectancy.

When an impairment causes few health problems and the disabling factors are the main difficulties, the health-care community must recognize that the affected individuals may not want to be "saved" by science. Value judgments regarding the quality of life of a person with a given disability must be made by the individual who lives with the disability, not by the researcher or clinician. While this approach may at times require difficult judgments about quality of life, it is preferable to the one-size-fits-all rules that assume that there is always a single "right" answer. ${ }^{12}$

The best way to balance the usefulness of biomedical and genetic research with concerns about its overuse and abuse is to educate health care professionals about disability and to keep the dialogue open between the disability community and the medical community. As the concept of personalized medicine emphasizes, different situations and different individuals require different solutions. These solutions can be best realized by maintaining awareness and sensitivity as we move through complex ethical and moral terrain. Geneticists should consider the implications of their research for those with disabilities, and recognize the impact of the historical trauma of the eugenics movement on perceptions of genetic research. This goal will be easier to achieve if people with disabilities are invited to participate in discussions about the professional and research policies that affect them. Dialogue can be messy, and at times uncomfortable, but it is the only way to avoid the mistakes of the past and to ensure a more equitable, and healthful, future.

\section{Acknowledgments}

This work was supported, in part, by the Center for Genomics and Healthcare Equality (grant P50 HG 3374 from the National Human Genome Research Institute) and by Dean Kellye Testy of the University of Washington School of Law. The views expressed are those of the authors and do not necessarily reflect the views of the funding agency or the institutions with which the authors were affiliated. Portions of this work were presented at the national meeting of the American Society of Human Genetics in October 2007. Our friend and colleague, P.S.M., died in 
October 2010. He left this text as part of the legacy of a career devoted to achieving equal rights and justice for persons with disabilities. Anna Mastroianni and Wylie Burke assisted his co-author, R.L.L., in preparing the manuscript for publication. P.S.M. was the Henry M. Jackson Professor of Law at the University of Washington School of Law.

\section{References}

1. [Accessed 20 April 2012] Ballastexistenz. http://ballastexistenz.autistics.org/

2. Huxley, A. Brave New World. Harper Collins; New York, NY: 1998. p. 179(originally published 1932)

3. Lombardo PA. Taking eugenics seriously: three generations of ??? are enough? Fla State Univ Law Rev. 2003; 30:191-218. [PubMed: 15083828]

4. Buck v. Bell, 274 U.S. 200 (1927). Buck v. Bell upheld a statute allowing state compulsory sterilization of people deemed to be "unfit," including people with mental disabilities, for the protection and health of the state. Carrie Buck, her mother, and her daughter were determined by the court to be "feeble-minded," although school records for both Carrie Buck and her daughter do not support such a finding. Carrie Buck and her mother were also determined to be promiscuous after bearing children out of wedlock.

5. Watson JD. President's essay: genes and politics. Annual Report Cold Spring Harbor. 1996; 14:120.

6. Watson, JD. A Passion for DNA: Genes, Genomes, and Society. Cold Spring Harbor Laboratory Press; Cold Spring Harbor, NY: 2000. p. 225

7. Abraham, C. Toronto Globe and Mail. Oct 26. 2002 Gene pioneer urges human perfection; p. A1

8. Singer, P. Practical Ethics. Cambridge University Press; Cambridge UK: 1979. p. 138(In the 1993 edition the term "defective" was replaced by "disabled.")

9. Quoted in Messall R. The long road of eugenics: from Rockefeller to Roe v. Wade. Hum Life Rev. 2004; 30:33-74. [PubMed: 15856597]

10. TallBear K. Narratives of race and indigeneity in the Genographic Project. J Law Med Ethics. 2007; 35:412-424. [PubMed: 17714251]

11. Struthers R, Lowe J. Nursing in the Native American culture and historical trauma. Issues Ment Health Nurs. 2003; 24:257-272. [PubMed: 12623685]

12. Shakespeare T. Disability, genetics, and global justice. Soc Policy \& Soc. 2005; 4:87-95.

13. Foucault, M. The Birth of the Clinic: An Archaeology of Medical Perception. Sheridan, Alan, translator. Vintage Books; New York, NY: 1973.

14. Kerr, A.; Shakespeare, T. Genetic Politics: From Eugenics to Genome. New Clarion Press; London: 2002.

15. Baynton DC. Defectives in the land: disability and American immigration policy, 1882-1924. J Am Ethnic Hist. 2005; 24(3):31-44.

16. Branigin, W. Washington Post. May 3. 2002 Warner apologizes to victims of eugenics; Woman who challenged sterilizations honored; p. B1

17. In Dred Scott v. Sanford, 60 U.S. 393 (1857), the US Supreme Court held that people of African descent brought to the United States and held as slaves were not protected by the Constitution and could not be citizens of the United States.

18. Plessy v. Ferguson, 163 U.S. 537 (1896) upheld the constitutionality of state laws requiring racial segregation in private businesses under the doctrine of "separate but equal."

19. Pfeiffer D. Eugenics and disability discrimination. Disabil Soc. 1994; 9:481-499. The Court in this case (Skinner v. Oklahoma, 316 U.S. 535 (1942)) was unwilling to recognize a distinction between the crimes of theft and embezzlement, and that a person convicted of larceny could be sterilized because of prior convictions, even though a conviction of embezzlement would not have led to involuntary sterilization.

20. Polirstok, S. [Accessed 20 April 2012] Buck v. Bell: a case study. Binghamton J His. 2002. http:// www2.binghamton.edu/history/resources/journal-of-history/buck-vs-bell.html

21. Kluchin, RM. Fit to be Tied: Sterilization and Reproductive Rights in America, 1950-1980. Rutgers University Press; New Brunswick, NJ: 2009. 
22. Ghent JF. Validity of statutes authorizing asexualization or sterilization of criminals or mental defectives. Am Law Rep ALR 3rd Cases Annot. 1973; 53:960-996. [PubMed: 12091928]

23. Mentally impaired persons. Am Jur 2d. 2008; 53:115.

24. North Carolina Ass'n for Retarded Children v. State of N.C., 420 F. Supp. 451, 457 (1976).

25. For example, Meyer v. Nebraska, 262 U.S. 390 (1923).

26. For example, Troxel v. Granville, 530 U.S. 57 (2000).

27. Pfeiffer D. Eugenics and disability discrimination. Disabil Soc. 1994; 9:481-499.

28. National Association of Social Workers/Connecticut Chapter. [Accessed 6 July 2012] Testimony on Bill. p. 7395http://www.cga.ct.gov/2007/JUDdata/Tmy/2007HB-07395-R000326-National $\%$ 20Association\%20of\%20Social\%20Workers,\%20Stephen\%20Karp-TMY.PDF

29. Despite a psychologist's testimony and a social worker's notes in support of Callo's ability to raise her children, Callo eventually agreed to allow them to be adopted in exchange for visitation rights and a promise that they would be raised together. However, the children were sent to separate families. Mathews J. Custody battle: the disabled fight to raise their children. Washington Post. Aug $18.1992:$ Z10.

30. After giving birth to a third child in 2002, Callo faced similar challenges, and was eventually forced to give up the child for adoption. Fisher P. A disabled mother fights again for right to raise her child. San Jose Mercury News. Dec 28.2007

31. [Accessed 6 July 2012] DPHHS settles disability discrimination lawsuit. <http:// theadvocate06.xanga.com/663989910/a-mother-fights-back-and-wins-against-child-services/>

32. Francis Galton coined the term "eugenics" in 1883 to describe "the study of the agencies under social control that may improve or impair the racial qualities of future generations, either physically or mentally." Forrest DW. Francis Galton: The Life and Work of a Victorian Genius. TaplingerNew York, NY1974:260.

33. What Every Body Worker/PT Needs to Know. Wheelchair Dancer; Oct 20. 2011 http:// cripwheels.blogspot.com/search/label/Wellness

34. Peace, W. Conjoined twins, disability, and ethics. bad cripple. Jun 10. 2010 http://badcripple.blogspot.com/2010/06/conjoined-twins-disabilty-and-ethics.html

35. WPAS Press Release. WPAS finds hospital that performed "Ashley treatment" Violated Law by Not Having Court Order. Disability Rights Washington. May 8. 2007 Web site. <http:// www.disabilityrightsca.org/newsarchive/AshleyPressRelease07may07.pdf>

36. Carlson, DR.; Dorfman, DA. Investigative Report Regarding the "Ashley Treatment". Washington Protection and Advocacy System; May 8. 2007 http://www.disabilityrightswa.org/home/ Full_Report_InvestigativeReportRegardingtheAshleyTreatment.pdf

37. In re Hayes, 93 Wn.2d 228, 236-37 (1980).

38. Kuusisto, S. [Accessed 20 April 2012] Growth attenuation: say it ain't so. Planet of the Blind. Jan 5. 2007 http://kuusisto.typepad.com/planet_of_the_blind/2007/01/say_it_aint_so.html

39. McDonald, A. Seattle Post-Intelligencer. Jun 17. 2007 The other story from a Pillow Angel.

40. Nichols, AD.; Ward, RL.; Freedman, RI. Left out in the Cold: Health Care Experiences of Adults with Intellectual and Developmental Disabilities in Massachusetts. The Arc of Massachusetts; Waltham, MA: 2008.

41. Wilson JC. (Re)writing the genetic body-text: disability, textuality, and the human genome project. Cultural Critique. 2002; 50:23-39.

42. Wyatt J. Medical paternalism and the fetus. J Med Ethics. 2001; 27(suppl 2):ii15-ii20. [PubMed: 11574653]

43. American Medical Association. [Accessed 20 April 2012] Code of Ethics: Article II §6. 1847. http://www.ama-assn.org/ama/pub/physician-resources/medical-ethics/code-medical-ethics.page

44. McCoy M. Autonomy, consent, and medical paternalism: legal issues in medical intervention. J Altern Complement Med. 2008; 14:785-792. [PubMed: 18601583]

45. AMA. Code of Medical Ethics: Current Opinions, 2000-2001. AMA Press; Chicago, IL: 2000. "The patient has the right to make decisions regarding the health care that is recommended by his or her physician. Accordingly, patients may accept or refuse any recommended medical 
treatment." American Medical Association. AMA Council on Ethical and Judicial Affairs, Opinion 10.01, Fundamental elements of the patient-physician relationship.

46. Quill TE, Brody H. Physician recommendations and patient autonomy: finding a balance between physician power and patient choice. Ann Intern Med. 1996; 125:763-769. [PubMed: 8929011]

47. Patient-Centered Model: "Encourages patients' individual needs and priorities because their beliefs, culture occupation or other factors may have a bearing on the information they need in order to reach decisions. Bridson J, Hammond C, Leach A, Chester MR. Making consent patient centered. BMJ. 2003; 327:1159-1161. [PubMed: 14615345]

48. Charlton, J. Nothing About Us Without Us. University of California Press; Berkeley, CA: 2000. p. 53

49. National Council on Disability. Privileges to Rights: People Labeled with Psychiatric Disabilities Speak for Themselves. National Council on Disability; Washington, DC: 2000.

50. [Accessed 21 July 2008] NTs Are Weird: An Autistic's View of the World. http:// thiswayoflife.org/blog/?p=270

51. Madeo AC, Biesecker BB, Brasington C, Erby LH, Peters KF. The relationship between the genetic counseling profession and the disability community. Am J Med Genet Part A. 2011; 155:1777-1785. [PubMed: 21567935]

52. Tervo RC, Palmer G, Redinius P. Health professional student attitudes towards people with disability. Clin Rehabil. 2004; 18:908-915. [PubMed: 15609846]

53. Albrecht GL, Devlieger PJ. The disability paradox: high quality of life against all odds. Soc Sci Med. 1999; 48:977-988. [PubMed: 10390038]

54. Hubbard S. Disability studies and health care curriculum: the great divide. J Allied Health. 2004; 33:184-188. [PubMed: 15503751]

55. The International Sub-Committee of The British Council of Disabled People. [Accessed 20 April 2012] The New Genetics and Disabled People. 2000. http://www.bcodp.org.uk/about/ genetics.shtml

56. Brosco JP, Mattingly M, Sanders LM. Impact of specific medical interventions on reducing the prevalence of mental retardation. Arch Pediatr Adolesc Med. 2006; 160:302-309. 303. [PubMed: 16520451]

57. Willis E. The 'new' genetics and the sociology of medical technology. J Sociol. 1998; 34:170-183.

58. Reality Check Woman. [Accessed 20 April 2012] Crip Chronicles. Feb 8. 2006 http:// teriadams.blogspot.com/search?q=genetic

59. Harmon, A. New York Times. Nov 20. 2005 The Problem With an Almost-Perfect Genetic World; p. WK1p. WK14

60. Scotch RK. Models of disability and the Americans with Disabilities Act. Berkeley J Employment \& Labor L. 2000; 21:213-222. 214.

61. Areheart BA. When disability isn't "just right": the entrenchment of the medical model of disability on disability and the Goldilocks dilemma. Ind L J. 2007; 83:181-232.

62. Smith SR. Distorted ideals: The "Problem of Dependency" and the mythology of independent living. Soc Theory Pract. 2001; 27:579-598. 595.

63. Some disability rights activists and scholars wish to push beyond the social model and instead look to the World Health Organization's blended medical-psychological-social model, which has been endorsed by Disabled Peoples' International. This blended approach recognizes that different situations require different approaches and acknowledges that there are different levels of a disabled person's experience. Shakespeare T. Disability, genetics, and global justice. Soc Policy \& Soc. 2005; 4:87-95.

64. American College of Obstetrics and Gynecology (ACOG). DPL Alert. 1985. Professional liability implications of AFP tests.

65. American College of Obstetrics and Gynecology (ACOG). Practice Bulletin No 77: screening for fetal chromosomal abnormalities. Obstet Gynecol. 2007; 109:217-227. [PubMed: 17197615]

66. Caruso T. Impact of prenatal screening on the birth status of fetuses with Down syndrome at an urban hospital, 1972-1994. Genet Med. 1998; 1:22-28. [PubMed: 11261425] 
67. Cheffins T, Chan A, Haan EA, et al. The impact of maternal serum screening on the birth prevalence of Down's syndrome and the use of amniocentesis and chorionic villus sampling in South Australia. BJOG. 2000; 107:1453-1459. [PubMed: 11192100]

68. Ekelund CK, Jørgensen FS, Petersen OB, Sundberg K, Tabor A. Danish Fetal Medicine Research Group. Impact of a new national screening policy for Down's syndrome in Denmark: population based cohort study. BMJ. 2008; 337:a2547. [PubMed: 19039015]

69. Khoshnood B, Pryde P, Blondel B, Lee KS. Socioeconomic and state-level differences in prenatal diagnosis and live birth prevalence of Down's syndrome in the United States. Rev Epidemiol Sante Publique. 2003; 51:617-627. [PubMed: 14967994]

70. Lai FM, Woo BH, Tan KH, et al. Birth prevalence of Down syndrome in Singapore from 1993 to 1998. Singapore Med J. 2002; 43:070-076. [PubMed: 11993893]

71. Siffel C, Correa A, Cragan J, Alverson CJ. Prenatal diagnosis, pregnancy terminations and prevalence of Down syndrome in Atlanta. Birth Defects Res Part A Clin Mol Teratol. 2004; 70:565-571. [PubMed: 15368554]

72. Liao GJ, Chan KC, Jiang P, et al. Noninvasive prenatal diagnosis of fetal trisomy 21 by allelic ratio analysis using targeted massively parallel sequencing of maternal plasma DNA. PLoS ONE. 2012; 7:e38154. [PubMed: 22666469]

73. Asch A. Prenatal diagnosis and selective abortion: a challenge to practice and policy. Am J Public Health. 1999; 89:1649-1657. [PubMed: 10553384]

74. Skotko BG, Levine SP, Goldstein R. Self-perceptions from people with Down syndrome. Am J Med Genet A. 2011; 155A:2360-2369. [PubMed: 21910246]

75. Stein MA. Labor markets, rationality, and workers with disabilities. Berkeley J Employment \& Labor L. 2000; 21:314-334. The medical model typically places people with disabilities into one of two categories: the "pitiable poster child" or the "inspirational supercrip." The poster child is seen as the object of pity and in need of charity ("sadcrip") while the supercrip is overcoming disability by her own heroic efforts and is determined to participate in everyday activities. The sadcrip-supercrip dichotomy is illustrated by comparing the disabled individuals portrayed on the Jerry Lewis telethon who are sadly smiling despite having lost the genetic lottery to the heroic stories of disabled individuals such as Christopher Reeve and Helen Keller.

76. Montgomery, C. [Accessed 20 April 2012] Mom can refuse sons' cochlear implants, says court. Ragged Edge. Oct 4. 2002 http://www.raggededgemagazine.com/drn/10_02.shtml\#446

77. Miller, PS. Toward truly informed decisions about appearance normalizing surgeries. In: Parens, E., editor. Surgically Shaping Children: Technology, Ethics, and the Pursuit of Normality. Johns Hopkins University Press; Baltimore, MD: 2006. p. 211

78. Oliver, M. The individual and social models of disability. Paper presented at The Joint Workshop of the Living Options Group and the Research Unit of the Royal College of Physicians; 23 July 1990; http://www.leeds.ac.uk/disability-studies/archiveuk/Oliver/in\%20soc\%20dis.pdf

79. One disability blogger is frustrated that any medical intervention that might be positive seems to be scorned: "without medical intervention I would not be able to work or socialize...," she says. "I'm not about to say, "Me and my impairments we're fine with each other so fork over the necessary dignity and respect." Instead, I'll say: "Give me some dignity and respect, dammit and right now, so that I can better bear the physical and emotional costs of my impairments."' Did I miss something? Medical Model, Social Model, and betwixt and between. Midlife and Treachery. Mar 3.2007 Accessed 21 July 2008http://midlifeandtreachery.blogspot.com/search?q=doctors 